\title{
NUTRITIONAL AND ECONOMICAL IMPACT OF USING SUPER STARTER DIETS IN FEEDING BROILER CHICKENS
}

\author{
A.I. El-Faham ${ }^{1}$; A.G. Abdallah' ${ }^{2}$; M.H.S. El-Sanhoury' ${ }^{1}$ and A.S.M. Arafa ${ }^{2}$ \\ ${ }^{1}$ Poultry Production Dept., Fac. of Agric., Ain Shams Univ., Egypt. \\ ${ }^{2}$ Dept. of Poult. Nut. Res., Anim. Prod. Res. Inst., Agric. Res. Center, Dokki, Giza, Egypt.
}

\section{SUMMARY}

\begin{abstract}
A experiment was conducted to study the effect of feeding recommended (23\%, Diet 1 ) or high $\left(25 \%\right.$, super starter, Diet $\left.{ }_{2}\right)$ crude protein in starter diets on productive performance, carcass characteristics and economical efficiency of Hubbard broiler chickens. A total of 225, day old Hubbard broiler male chicks were randomly distributed into 5 treatments at (1-35) days of age, each with three replicates of 15 birds each. The five treatments were: $T_{1}$ ) Control group, chicks fed $\left(\right.$ Diet $\left._{1}\right)$ ad-libitum the other treatments from $T_{2}$ till $T_{5}$, chicks were fed (Diet ${ }_{2}$ )at different quantities being $125 \mathrm{~g}, 250 \mathrm{~g}, 375 \mathrm{~g}$ and $500 \mathrm{~g} / \mathrm{chick}$, respectively followed by $\left(\mathrm{Diet}_{1}\right)$ to the end of starter period (14 days of age). During grower and finisher periods, all chicks were fed recommended diets at these phases. At the end of experiment at 35 days of age, 4 broilers chicken per treatment were slaughtered and evaluated for carcass traits. The results indicate that: Body weight, body weight gain and feed intake were linearly increased, whereas feed conversion ratio decreased as super starter diet increased, during overall period (1-35 days of age). The best values of body weight gain, feed conversion ratio, protein and energy conversion ratio were observed for chickens fed 500g super starter diet compared with other dietary treatments. In most cases differences between treatments were significant $(\mathrm{P} \leq 0.01)$. Carcass characteristics of chicks fed super starter diet, added at different levels had no effects on carcass characteristics. The best economical efficiency value were demonstrated when broiler chickens fed (500g Diet $2 /$ chick) super starter diet and the values was $33.09 \%$ more when compared to that of chicks fed control diets. In conclusion, feeding broiler chickens super starter diet at level of (500g/chick) support and enhance productive performance and economical efficiency.
\end{abstract}

Keywords: Broiler performance, carcass characteristics, super starter diet, economic efficiency.

\section{INTRODUCTION}

Global poultry meat and egg production as well as trade with poultry products have shown a remarkable dynamic during the last 35 years. Between 1970 and 2005 poultry meat increased faster than beef and veal or pigment production Windhorst (2006). Therefore, a better understanding and updating of the nutritional requirements of broiler chickens under Egyptian conditions is needed in order to reach its potential in poultry industry.

Energy and protein are an important nutritional, representing majority of total cost of the diets and the most economically factors affecting profitability for boiler chickens (Sterling et al., 2005 and El-Fahamet al., 2016a).

Increasing profitability of broiler chickens production is dependent on reducing input costs and/or increasing production output. Any reduction in feed cost/chickens or improved in feed efficiency without compromising growth rate or carcass quality can have a significant positive economic impact on broiler chickens production (Sterling et al., 2005).

Several experiments with broiler chicks or quails have shown that performance is adversely affected with low crude protein diets and investigated the potential reasons for decreasing performance and economic efficiency (Mosaad and Iben, 2009; Malomoand Olutade, 2013; Folorunsoet al., 2014 and Ali, 2006). Similar results were observed by (Bregendahlet al., 2002; Sterling et al., 2005 and Waldroupet al. 2005) indicated that, rate and efficiency of growth is lowered and carcass composition becomes inferior in broilers fed diets in which crude protein has been lowered by more than $2.5 \%$ of the chicken requirements, even when all known nutrient requirements are supplemented such as amino acids. On the other hand, some researcher's studies had found that reducing dietary crude protein does not affect growth performance and carcass traits (Parr and Summaers, 1991, Moran and Stilborn, 1996, Saleh 2016 and El-Fahamet al., 2016). Therefore, in the present study, an experiment was conducted to investigate the 
effect of feeding recommended or high crude protein in starter diets on productive performance, carcass characteristics and economicalefficiency of Hubbard broiler chickens.

\section{MATERIALS AND METHODS}

\section{Birds and management:}

This study was conducted at a private local broiler farm, Monufia governorate. A total number of 225 Hubbard broiler male chicks, day old, were randomly allotted to 5 dietary treatments (45 chicks per treatment) in 3 replicates (15 chicks/replicate). Chicks were housed in battery cages, kept under similar environmental and managerial conditions during 1-35 days of age. Feed and water were offered adlibitum all over the experimental period.

\section{The experimental diets:}

Two starter diets were formulated to contain and $\left(23.01 \% \mathrm{CP}\right.$ with $3046 \mathrm{kcal} / \mathrm{kg}$; starter, Deit $\left.{ }_{1}\right)$ (25.01\% CP with $2918 \mathrm{kcal} / \mathrm{kg}$; super starter, Deit ${ }_{2}$ ) for starter phase (1-14) days of age, while during grower phase (15- 28d) chicks were fed $\left(21.01 \% \mathrm{CP}\right.$ with $3159 \mathrm{kcal} / \mathrm{kg}$, Deit $\left.{ }_{3}\right)$ and during finisher phase (29- 35d) chick fed (19.04\% CP with $3238 \mathrm{kcal} / \mathrm{kg}$, Deit $\left.{ }_{4}\right)$. Methionine, Lysine and mixture of vitamins and minerals were added to cover the requirement of Hubbard chicks according to NRC, 1994.

Chicks were distributed into five treatments in starter period as follows: $\mathrm{T}_{1}$ : Control group, chicks fed (Diet ${ }_{1}$ ) ad-libitum and $\mathrm{T}_{2}-\mathrm{T}_{5}$ groups, chicks fed $125 \mathrm{~g}, 250 \mathrm{~g}, 375 \mathrm{~g}$ and $500 \mathrm{~g} /$ chicks $\left(\right.$ Diet $\left._{2}\right)$ respectively followed by $\left(\right.$ Diet $\left._{1}\right)$ to the end of starter period (14) days of age then all experimental chicks fed grower and finisher diets $\left(\right.$ Diet $\left._{3-4}\right)$. Feed ingredients and chemical analysis of the diets used in this experiment are shown in Table (1).

\section{Data collection:}

\section{Growth performance parameters:}

Live body weight and feed intake of broiler chicks were recorded. While, body weight gain and feed conversion ratio were calculated. Performance index was measured according to North (1981), where production efficiency factor according to Emmert (2000).

Also, the protein conversion ratio (PCR) and energy conversion ratio (ECR) were calculated for overall period.

\section{Carcass characteristics:}

At the end of experimental period (35 days of age), four broilers chicks per treatments were randomly taken and slaughtered. Data of carcass traits were calculated as \% of live body weight (Carcass $\%$ and giblets\%).

\section{Economical efficiency:}

The economical efficiency for broiler chicks (meat production) was calculated according to the price of local market for feed ingredients and selling price of line broiler chickens at the time of the experimental (March/2017). Economical efficiency $=$ the net revenue/total cost.

\section{Statistical analysis:}

Statistical analysis was conducted using the General linear Model (GLM) procedure of SAS (2004). Means were compared using Duncan's Multiple Range Test (Duncan, 1955) and level of significance was set at minimum of $(\mathrm{P} \leq 0.05)$. The statistical model was

Where:

$$
Y_{i j}=\mu+T_{i}+e_{i j}
$$

$\mathrm{Y}_{\mathrm{ij}}=$ observation of the parameter measured.

$\mathrm{T}_{\mathrm{i}}=$ effect of treatment (i : 1 to 5).

$\mu=$ overall mean.

$\mathrm{e}_{\mathrm{ij}}=$ random error. 


\section{RESULTS AND DISCUSSION}

\section{Productive Performance:}

\section{Live Body weight (LBW) and body weight gain (BWG):}

There were a significant difference $(\mathrm{P}<0.01)$ in $\mathrm{LBW}$ and $\mathrm{BWG}$ values due to experimental treatments (Table 2) Results show that the worest values of LBW and BWG had been obtained by broiler chicks fed control diet $\left(\mathrm{T}_{1}\right)$ compared with the other treatment $\left(\mathrm{T}_{2}\right.$ till $\left.\mathrm{T}_{5}\right)$. The explanation of that could be related to the fact that, Excess protein level in super starter $\left(\right.$ Diet $\left._{2}\right)$ improve BWG in Comparison with the control diet $\left(\right.$ Diet $_{1}$ ) or Diet2 (super starter) was formulated to meet the optimum nutrient requirements for broiler chicks based on the recommendations of NRC (1994).

On the other hand, chicks fed $375 \mathrm{~g}$ or $500 \mathrm{~g}$ from Diet $2\left(\mathrm{~T}_{4}\right.$ and $\mathrm{T}_{5}$ ) gave higher LBW (2155g and $2226.67 \mathrm{~g}$ respectively). Compared to those fed lower quantity of $\operatorname{diet}_{2}\left(\mathrm{~T}_{2}\right.$ and $\left.\mathrm{T}_{3}\right)$, Being 2028.33 and 2046.67 (g) respectively and the differences failed to be significant.

In the same trend, responses of chicks fed either $\left(375 \mathrm{~g} \mathrm{Diet} \mathrm{T}_{4}\right)$ or $500 \mathrm{~g} \operatorname{Diet}_{2}\left(\mathrm{~T}_{5}\right)$ significantly higher BWG than those fed the two other lower levels of $\operatorname{Diet}_{2}\left(\mathrm{~T}_{2}\right.$ and $\left.\mathrm{T}_{3}\right)$ and the difference were statistically significant compared with those fed control diet $\left(\mathrm{T}_{1}\right)$. These results are agreement with those obtained by Gheisari et al. (2011) who reported that feeding growing quail diet contained high protein level (24\%) improved body weight as compared with quail received the lower protein level $(21 \% \mathrm{CP})$. Moreover, El- Faham et al. (2016a,b) and Karman et al. (2008), stated that live body weight and weight gain of broiler chickens was linearly decreased as dietary protein and energy decreased during experimental periods. On the other hand, these findings were in contrast with the results obtained by Saleh (2016) who reported that feeding (Cobb Avian, 48) broilers on 1\% lower protein diets than the strain recommendation, at constant $\mathrm{ME}$, had not adversely affected the growth performance.

In another study conducted by Abd- Elsamee (2001 and 2002) found that chicks fed low protein diets (ranged from 21 to $17 \% \mathrm{CP}$ ) supplemented with essential amino acids had similar growth rate and feed efficiency as those fed $23 \%$ CP diet. The same observation was reported by Harms and Russell (1993) on laying hens.

\section{Feed intake (FI) and feed conversion ratio (FCR):}

The obtain date show that, there were significant differences in feed intake and feed conversion ratio among treatment during whole overall period (1-35) days of age. It was obvious from (Table 2) that feed intake per bird $(\mathrm{g})$ was significantly $(\mathrm{P}<0.01)$ increased by feeding $\left(\operatorname{Diet}_{2}\right),\left(\mathrm{T}_{2}-\mathrm{T}_{5}\right)$ compared with those fed control diet $\left(\mathrm{T}_{1}\right)$. The increase in feed consumption was ranged between 9.2 and $18.5 \%$, with significant differences between treatments.

In the same order, the values of FCR indicted significant differences between birds fed $250 \mathrm{~g}, 375 \mathrm{~g}$ and 500g Diet $2\left(\mathrm{~T}_{3}, \mathrm{~T}_{4}\right.$ and $\left.\mathrm{T}_{5}\right)$, compared with those fed control $\left(\mathrm{T}_{1}\right)$ or $125 \mathrm{~g} \operatorname{Diet}_{2}\left(\mathrm{~T}_{2}\right)$. The best FCR was detected for the birds fed $500 \mathrm{~g} \operatorname{Diet}_{2}\left(\mathrm{~T}_{5}, 1.59\right)$. On the other hand, the worst FCR were found in birds fed the control diet or $125 \mathrm{~g} \mathrm{Diet}_{2}$ being the same rate 1.64 , respectively.

Which could be to the highest body weight gain, since birds fed $\left(\mathrm{T}_{5}\right)$ diet were more efficient in converting their food into body weight gain compared with those fed control diets $\left(\mathrm{T}_{1}\right)$. Similar results were observed by Kamran et al. (2008) and El-Faham et al. (2016a,b) in broiler chickens and Harms and Russell (1993) in laying hens and Abdel-Azeem et al. (2005)in Japanese quail and Gheisari et al. (2011) on growing quail.

\section{Growth rate:}

Significant differences $(\mathrm{P}<0.05)$ were observed in growth rate between experimental treatments during whole experimental period (Table 2)where, feeding chicks with 375 and $500 \mathrm{~g} \mathrm{Diet}_{2}\left(\mathrm{~T}_{4}\right.$ and $\left.\mathrm{T}_{5}\right)$ showed the highest (1.93) growth rate followed by those fed $125 \mathrm{~g}$ and $250 \mathrm{~g} \operatorname{Diet}_{2}\left(\mathrm{~T}_{2-3}, 1.92\right)$, while chickens fed control diet $\left(\mathrm{T}_{1}\right)$ had the lowest value being (1.91) and in most cases differences were significant.

\section{Protein conversion ratio (PCR) and energy conversion ratio (ECR):}

The results concerning the effect of dietary treatments on the PCR and ECR are shown in Table (3). The values of PCR and ECR indicated significant differences between birds fed $250 \mathrm{~g}, 375 \mathrm{~g}$ and $500 \mathrm{~g}$ Diet $_{2}$, compared with those fed control $\mathrm{T}_{1}$ or fed $125 \mathrm{~g} \operatorname{Diet}_{2}\left(\mathrm{~T}_{2}\right)$ diets. The best values were detected for 
the broiler chicks fed $\mathrm{T}_{5}$ diet. The corresponding rates were 0.33 and 5.0 respectively. On the other hand, the worst PCR and ECR values were found in birds fed control diets (being 0 and 5.36, respectively).

\section{Performance index (PI) and productive efficiency factors (PEF):}

The obtained date showed that, there were significant different in PI and PEF among various treatments (from $\mathrm{T}_{1}$ till $\mathrm{T}_{5}$ ) during the studied period (1-35 days). Data in Table (3) indicated that PI and PEF values were significantly increased by increasing super starter diets $\left(\right.$ Diet $\left._{2}\right)$ for broiler chickens (from $\left.\mathrm{T}_{2}-\mathrm{T}_{5}\right)$ as compared to those fed control diets $\left(\mathrm{T}_{1}\right)$. In addition, chickens fed $\left(\mathrm{T}_{5}\right)$ diets gave the highest values (139.74 and 399.26) compared to those fed control diets being 111.41 and 318.32, respectively, however, differences failed to be significant. Similar observations were reported by Awad et al. (2014), who reported that significant differences were observed in PI between experimental treatments due to varing $\mathrm{ME}, \mathrm{CP}$ levels and duckling sex during experiment periods (2-20 wks). On the other hand, these findings are in contrast with the results obtained by Kout El-Kloub et al. (2010) who reported that PIU values were insignificantly decreased by increasing both ME and CP levels in Domyati duckling diets during 0-12wks, of age.

\section{Carcass characteristics:}

Table (4) shows the effect of super starter $\operatorname{diet}_{2}$ on some carcass characteristics for the male chickens at the end of 35 days of age. Experimental treatments $\left(\mathrm{T}_{2-5}\right)$ had no significant effect on studied parameters compared with control $\left(\mathrm{T}_{1}\right)$. The corresponding values for dressed carcass percentages ranged between 64.17 and $66.22 \%$, while giblets percentages (liver + gizzard + heart) percentages ranged between 4.10 and $4.55 \%$. In addition, chickens fed control diets gave numerally the lowest dressed carcass \% (64.17) compared to those fed different dietary treatments from $\mathrm{T}_{2^{-}} \mathrm{T}_{5}$, being 66.22, 65.19, 65.91 and 65.49 respectively and differences among treatments were insignificant. Similar observations were reported by other investigators Malomoand Olutade (2013), Abd-Elsamee et al. (2014), El-Faham et al. (2015 and 2016), theyconcluded that no significant different in carcass characteristics for the broiler chicks feeding low protein diet or different ME levels.

\section{Economical efficiency:}

Data presented in Table (5) show the economical efficiency of the different dietary treatments $\left(\mathrm{T}_{1}-\mathrm{T}_{5}\right)$ and money returned per chicken at the end of experimental period as affected by different levels of super starter $\operatorname{diet}_{2}$. Live body weight, feed intake and feed cost are generally among the most important factors involved in achieve maximum profit from meat production. Results show that, the lowest values of net return (LE) and economical efficiency were recorded for the control treatment $\left(\mathrm{T}_{1}\right)$, being 13.84 and 43.33 , respectively. While the highest values were recorded for $\left(\mathrm{T}_{5}\right)$ treatment and the corresponding values were 20.36 and 57.67 respectively. Moreover, feeding super starter $\operatorname{diet}_{2}$ by different levels from $\mathrm{T}_{2}$ till $\mathrm{T}_{5}$ gave the highest relative economic efficiency and the corresponding values were 114.16, 120.57, 126.52 and 133.09 respectively.

\section{CONCLUSION}

From the present results, it could be stated that, feeding Hubbard broiler chicks super starter diet at $(500 \mathrm{~g} / \mathrm{chick})$, would have a positive effect on productive performance and economical efficiency, without any adverse effect on carcass characteristics.

\section{REFERENCES}

Abdel-Azeem, F.A.; G.M. Nematallah and Faten, A.A. Ibrahim (2005). Effect of dietary protein levels with some natural biological feed additives supplementation on productive and phycological performance of Japanese quails. Egypt. Poult. Sci. 25: 497-525.

Abd-Elsamee, M.O. (2001). Broiler performance as affected by crude protein, lysine and a probiotic. Egypt. Poult. Sci. 21: 943-962.

Abd-Elsamee, M.O. (2002). Effect of different levels of crude protein, Sulphur amino acids, microbial phytase and their interaction on broiler chicks performance. Egypt. Poult. Sci., 22: 999-1021.

Ali, A.M. (2006). Performance of laying Japanese quail fed low protein diet supplemented with methionine and lysine. Egypt Poult. Sci. 26:857-872. 
Awad, A.L.; KoutElkloub, M. Al-Moustafa; A.I.A. Ghonim and Nehad, A. Ramadan (2014). Comparative study for different levels of energy and protein in Sudani ducklings diet during growth period. Egypt. Poult. Sci., 34: 537-560.

Bregendahl, K.; J.L. Sell and D.R. Zimmerman (2002). Effect of low protein diets on growth performance and body composition of broiler chickens. Poult. Sci. 81: 1156-1167.

Duncan, D.B. (1955). Multiple ranges and multiple F test. Biometrics, 11: 1-42.

El-Faham, A.I.; Nematallah, G.M. Ali and A.Y.M. Abdelhady (2016a). Effects of low energy diets having constant energy-to-protein ratio on productive performance of broilers. $9^{\text {th }}$ Int. Poult. Con. Hurghada Red Sea. Egypt. 246-267.

El-Faham, A.I.; Nematallah, G.M. Ali. and Rahman M. Ali (2016b). Effect of feeding different dietary energy levels on productive and physiological performance of broiler chicks under different housing systems. Egypt. J. Nutr. Feeds 18: 301-310.

Folorunso, O.R.; A.A. Adesua and G.A. Onibi (2014). Response of broiler chickens to diets of varying protein contents under ad-libitum and skip-a-day feeding regimes. African J. Agric. Res., 9: 113-118.

Gheisari, A.; H. Halajil; G. Maghsoudinegad; M. Toghyanil; A. Alibemani and S.E. Saeid (2011). Effect of different dietary levels of energy and protein on performance of Japanese quails (CoturnixCoturnixJapanica) $2^{\text {nd }}$ International Conference on Agricultural and Animal Science IPCBEE, 25-27 November 2011, Maldives, Asia, pp. 156-159.

Harms, R.H. and G.B. Russell (1993). Optimizing egg mass with amino acids supplementation of lowprotein diet. Poult. Sci., 72: 1892-1896.

Kamran, Z.; M. Sarwar; M. Nisa; M.A. Nadeen; S. Mahmood; M.E. Babar and S. Ahmed (2008). Effect of low-protein diets having constant energy-to-protein ratio on performance and carcass characteristics of broiler chickens from one to thirty-five days of age. Poult. Sci. 87: 468-474.

KoutElkloub, M. El-Moustafa; A.L. Awad and A.I.A. Ghonim (2010). Response of Domyati ducklings to diets containing different levels of metabolizable energy and crude protein: 1-During growth period. Egypt. Poult. Sci., 30: 535-564.

Malomo, G.A. and S.G. Olutade (2013). Effects of dietary crude protein on performance and nitrogen economy of broilers. Sustainable Agric. Res. 2: 52-57.

Moran, E.T. and H.L. Stilborn (1996). Effect of glutamic acid on broiler given sub-marginal crude protein with adequate essential amino using feeds high and low in potassium. Poult. Sci. 75: 120-129.

Mosaad, G.M. and C. Iben (2009). Effect of dietary energy and protein levels on growth performance, carcass yield and some blood constituents of Japanese quails (coturnixcoturnix Japonica). Die Bodenkultur, 60: 39-46.

NRC (1994). National Research Council. Nutrient Requirements of poultry. $9^{\text {th }}$ Ed. Composition of poultry feedstuffs. National Academy Press, Washington, DC, USA. P.P. 61-75.

Parr, J.F. and J.D. Summaers (1991). The effects of minimizing amino acids excesses in broiler diets. Poult. Sci. 70: 1540-1549.

Saleh, A.A. (2016). Effect of low-protein in Iso- energetic diets on performance, carcass characteristics, digestibilities and plasma lipids of broilers chickens. Egypt. Poult. Sci. 36: 251-262.

SAS (2004). SAS procedure guide version 6. $12^{\text {th }}$ Ed. SAS institute Inc., Cary, NC, and U.C.A.

Sterling, K.G.; D.V. Vedenov; G.M. Pesti and R.I. Bakalli (2005). Economically optimal crude protein and lysine levels for starting broiler chicks. Poult. Sci. 84: 29-36.

Waldroup, P.W.; Q. Jiang and C.A. Fritts (2005). Effects of glycine and threonine supplementation on performance of broiler chicks fed diets low in crude protein. Int. J. Poult. Sci. 4: 250-257.

Windhorst, H.W. (2006). Changes in poultry production and trade worldwide. World's Poult. Sci. J. 62: 585-602. 
El-Faham et al. 
التأثير الغذائى والاقتصادى لاستخدام عليقة السوبر بادئ فى تغذية بدارى التسمين

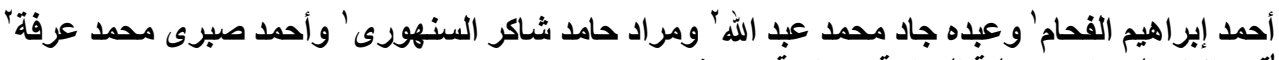

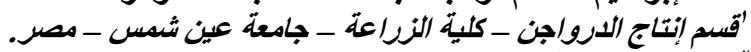

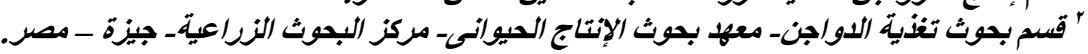

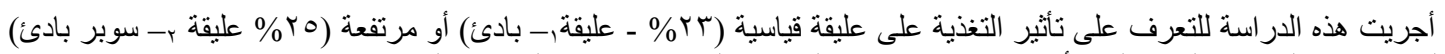

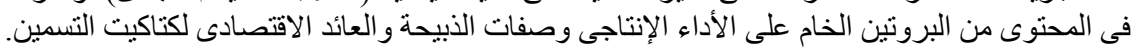

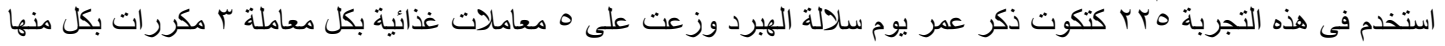

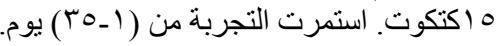

عليقة,

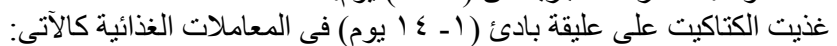

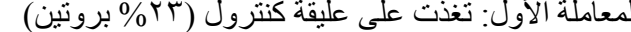

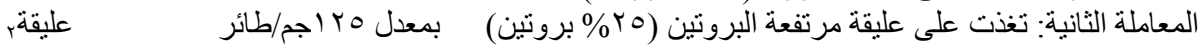

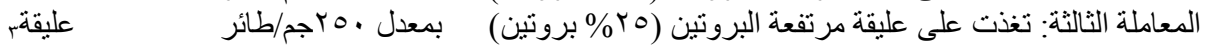

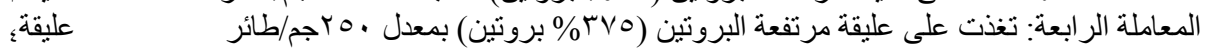

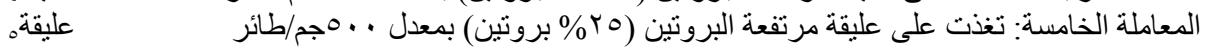

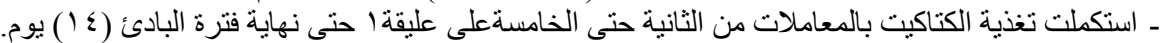
ـ غذيت كتاكيت التجربة والتى غطى الاحتياجات الغذائية للسلالة من المعاملة الأولى حتى الخامسة على على عليقة النامى (10 ـ بـ يوم) ثم

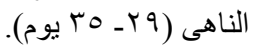
وكانت النتائج المتحصل عليها كالآتى: اــ زيادة الوزن الحي والوزن المكتسب واستهلاك العلف وتحسن معامل التحويل الغذائى بزيادة كمية السوبر بادئ المقدة لبدارى

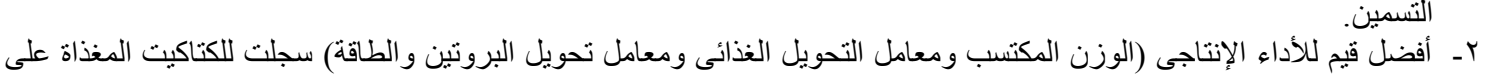

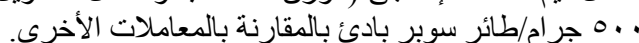
كـ لم تتأثر معنويًا جميع قياسات الذيبحة كنسبة مئوية للوزن الحى للطائر (الذبيحة، الحوائج، قلب، كبد، قانصة) بالمعاملات الغذائية المختلفة. عـ أفضل قيم للكفاءة الاقتصادية سجلت للكتاكيت المغذاة على . .

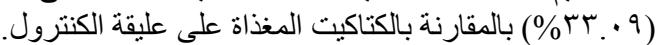
الخلاصة: تغذية كتاكيت بدارى التسمين على عليقة سوبر بادي بمعدل (0. •كجم/ طائر) أثناء فترة البادئ يحسن الأداء الإنتاجى والعائد الاقتصادى. تلغذيك. 
Table (1): Feed ingredients and chemical analyses of experimental diets.

\begin{tabular}{|c|c|c|c|c|}
\hline \multirow[b]{2}{*}{ Ingredients } & \multicolumn{4}{|c|}{ Experimental Diets } \\
\hline & $\begin{array}{c}\text { Starter } \\
\text { (Diet 1) }\end{array}$ & $\begin{array}{l}\text { Super Starter } \\
\text { (Diet 2) }\end{array}$ & $\begin{array}{l}\text { Grower } \\
\text { (Diet 3) }\end{array}$ & $\begin{array}{l}\text { Finisher } \\
\text { (Diet 4) }\end{array}$ \\
\hline Yellow Corn Grains & 51.55 & 48.59 & 57.23 & 62.59 \\
\hline Soy Bean Meal (44\%) & 35.00 & 39.00 & 29.79 & 24.70 \\
\hline Corn Gluten Meal (60\%) & 5.20 & 6.00 & 4.90 & 4.60 \\
\hline Limestone $\left(\mathrm{CaCO}_{3}\right)$ & 1.35 & 1.35 & 1.10 & 1.08 \\
\hline Di-Ca Phosphate & 1.90 & 1.90 & 1.68 & 1.55 \\
\hline Salt $(\mathrm{NaCl})$ & 0.40 & 0.40 & 0.40 & 0.40 \\
\hline Premix* & 0.30 & 0.30 & 0.30 & 0.30 \\
\hline Soy Oil & 3.50 & 2.00 & 4.00 & 4.25 \\
\hline DL-Methionine & 0.31 & 0.24 & 0.24 & 0.21 \\
\hline Lysine $-\mathrm{HCl}$ & 0.32 & 0.20 & 0.25 & 0.23 \\
\hline Anti-Oxidant & 0.17 & 0.02 & 0.11 & 0.09 \\
\hline Total & 100 & 100 & 100 & 100 \\
\hline \multicolumn{5}{|c|}{ Chemical Analysis (Calculated) ${ }^{* *}$} \\
\hline Crude Protein \% & 23.01 & 25.01 & 21.01 & 19.04 \\
\hline ME Kcal/ Kg diet & 3046 & 2918 & 3159 & 3238 \\
\hline Calcium $\%$ & 1.07 & 1.06 & 0.90 & 0.85 \\
\hline Available Phosphorus \% & 0.51 & 0.49 & 0.45 & 0.42 \\
\hline Lysine \% & 1.45 & 1.44 & 1.25 & 1.10 \\
\hline Methionine \& Cysteine \% & 0.69 & 0.66 & 0.60 & 0.54 \\
\hline Price/ Ton (L.E.) & 6707 & 6696 & 6449 & 6199 \\
\hline
\end{tabular}

"Each $3 \mathrm{Kg}$ of premix contains: Vitamins: A: $12000000 \mathrm{IU}$; Vitamins; D3 $2000000 \mathrm{IU}$; E: $10000 \mathrm{mg}$; K3:

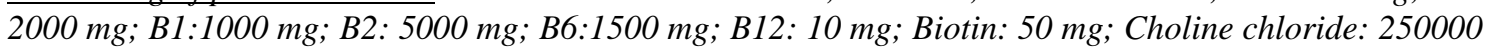
mg; Pantothenic acid: 10000 mg; Nicotinic acid: 30000 mg; Folic acid: 1000 mg; Minerals: Mn: 60000 mg; Zn: $50000 \mathrm{mg}$; Fe: $30000 \mathrm{mg}$; Cu: $10000 \mathrm{mg}$;: $1000 \mathrm{mg}$; Se: $100 \mathrm{mg}$ and Co: $100 \mathrm{mg}$.

*** According to NRC, 1994.

Table (2): Effect of different dietary treatments on productive performance.

\begin{tabular}{|c|c|c|c|c|c|c|}
\hline \multirow{2}{*}{ Items } & \multicolumn{6}{|c|}{ Dietary Treatments } \\
\hline & 1 & 2 & 3 & 4 & 5 & Sig. \\
\hline Live body weight (g) & $\begin{array}{l}1830.00^{c} \\
\pm 47.25\end{array}$ & $\begin{array}{r}2028.33^{\mathrm{b}} \\
\pm 39.19\end{array}$ & $\begin{array}{l}2046.67^{b} \\
\pm 28.91\end{array}$ & $\begin{array}{l}2155.00^{\mathrm{a}} \\
\pm 24.66\end{array}$ & $\begin{array}{l}2226.67^{\mathrm{a}} \\
\pm 14.52\end{array}$ & $* *$ \\
\hline Body weight gain (g) & $\begin{array}{c}1790.00^{\mathrm{c}} \\
\pm 47.25\end{array}$ & $\begin{array}{r}1988.33^{\mathrm{b}} \\
\pm 39.19\end{array}$ & $\begin{array}{c}2006.67^{b} \\
\pm 28.91\end{array}$ & $\begin{array}{l}2115.00^{\mathrm{a}} \\
\pm 24.66\end{array}$ & $\begin{array}{l}2186.67^{\mathrm{a}} \\
\pm 14.52\end{array}$ & $* *$ \\
\hline Feed intake $(\mathrm{g})$ & $\begin{array}{l}2940.67^{\mathrm{c}} \\
\pm 71.05\end{array}$ & $\begin{array}{l}3261.67^{\mathrm{b}} \\
\pm 82.89\end{array}$ & $\begin{array}{l}3211.00^{\mathrm{b}} \\
\pm 57.76\end{array}$ & $\begin{array}{c}3402.33^{\mathrm{ab}} \\
\pm 38.30\end{array}$ & $\begin{array}{r}3484.33^{\mathrm{a}} \\
\pm 41.57\end{array}$ & $* *$ \\
\hline $\begin{array}{l}\text { Feed conversion ratio (feed/ } \\
\text { gain) }\end{array}$ & $\begin{array}{l}1.64^{\mathrm{a}} \\
\pm 0.01\end{array}$ & $\begin{array}{l}1.64^{\mathrm{a}} \\
\pm 0.01\end{array}$ & $\begin{array}{l}1.60^{\mathrm{b}} \\
\pm 0.01\end{array}$ & $\begin{array}{l}1.61^{\mathrm{b}} \\
\pm 0.01\end{array}$ & $\begin{array}{l}1.59^{\mathrm{b}} \\
\pm 0.01\end{array}$ & $* *$ \\
\hline Growth rate & $\begin{array}{l}1.91^{\mathrm{b}} \\
\pm 0.01\end{array}$ & $\begin{array}{l}1.92^{\mathrm{ab}} \\
\pm 0.01\end{array}$ & $\begin{array}{l}1.92^{\mathrm{ab}} \\
\pm 0.01\end{array}$ & $\begin{array}{l}1.93^{\mathrm{a}} \\
\pm 0.01\end{array}$ & $\begin{array}{l}1.93^{\mathrm{a}} \\
\pm 0.01\end{array}$ & $*$ \\
\hline
\end{tabular}

$a, b, c, d$ Means within the same row with different superscripts are significantly different.

Sig. $=$ Significance, ${ }^{* *}(P \leq 0.01), *(P \leq 0.05)$. 
Table (3): Effect of different dietary treatments on protein and energy conversion ratio (PCR, ECR), performance index (PI) and production efficiency factor (PEF).

\begin{tabular}{|c|c|c|c|c|c|c|}
\hline \multirow{2}{*}{ Items } & \multicolumn{6}{|c|}{ Dietary Treatments } \\
\hline & 1 & 2 & 3 & 4 & 5 & Sig. \\
\hline $\begin{array}{l}\text { PCR: Protein conversion ratio } \\
\text { (g protein/g gain) }\end{array}$ & $\begin{array}{l}0.35^{\mathrm{a}} \\
\pm 0.01\end{array}$ & $\begin{array}{l}0.35^{\mathrm{a}} \\
\pm 0.01\end{array}$ & $\begin{array}{l}0.34^{\mathrm{ab}} \\
\pm 0.01\end{array}$ & $\begin{array}{l}0.34^{\mathrm{ab}} \\
\pm 0.01\end{array}$ & $\begin{array}{l}0.33^{\mathrm{b}} \\
\pm 0.01\end{array}$ & $*$ \\
\hline $\begin{array}{l}\text { ECR: Energy conversion ratio } \\
\text { (Kcal/ g gain) }\end{array}$ & $\begin{array}{l}5.36^{\mathrm{a}} \\
\pm 0.08\end{array}$ & $\begin{array}{l}5.23^{\mathrm{a}} \\
\pm 0.04\end{array}$ & $\begin{array}{l}5.08^{\mathrm{b}} \\
\pm 0.01\end{array}$ & $\begin{array}{l}5.06^{\mathrm{b}} \\
\pm 0.01\end{array}$ & $\begin{array}{l}5.00^{\mathrm{b}} \\
\pm 0.01\end{array}$ & $* *$ \\
\hline Performance Index ${ }^{1}$ (PI) & $\begin{array}{l}111.41^{\mathrm{d}} \\
\pm 3.35 \\
\end{array}$ & $\begin{array}{r}123.66^{\mathrm{c}} \\
\pm 1.80 \\
\end{array}$ & $\begin{array}{c}127.90^{\mathrm{bc}} \\
\pm 1.38 \\
\end{array}$ & $\begin{array}{c}133.96^{\mathrm{ab}} \\
\pm 1.60 \\
\end{array}$ & $\begin{array}{c}139.74^{\mathrm{a}} \\
\pm 0.38 \\
\end{array}$ & $* *$ \\
\hline $\begin{array}{l}\text { Production Efficiency Factor } \\
\quad \text { (PEF) }\end{array}$ & $\begin{array}{c}318.32^{\mathrm{d}} \\
\pm 9.59\end{array}$ & $\begin{array}{l}353.31^{\mathrm{c}} \\
\pm 5.15\end{array}$ & $\begin{array}{c}365.44^{\mathrm{bc}} \\
\pm 3.93\end{array}$ & $\begin{array}{c}382.76^{\mathrm{ab}} \\
\pm 4.57\end{array}$ & $\begin{array}{c}399.26^{\mathrm{a}} \\
\pm 1.10\end{array}$ & $* *$ \\
\hline
\end{tabular}

$a, b, c$ Means within the same row with different superscripts are significantly different. Sig. = Significance $* *$ $(P \leq 0.01), *(P \leq 0.05)$. 1: North (1981); 2: Emmert (2000).

Table (4): Effect of dietary treatments on some carcass characteristics.

\begin{tabular}{lcccccc}
\hline \multirow{2}{*}{ Items } & \multicolumn{5}{c}{ Dietary Treatments } \\
\cline { 2 - 7 } & 1 & 2 & 3 & 4 & 5 & Sig. \\
\hline Dressed carcass \% & $64.17 \pm 0.35$ & $66.22 \pm 0.21$ & $65.19 \pm 1.07$ & $65.91 \pm 0.41$ & $65.49 \pm 0.99$ & NS \\
\hline Liver \% & $2.68 \pm 0.24$ & $2.47 \pm 0.29$ & $2.84 \pm 0.66$ & $2.96 \pm 0.24$ & $2.52 \pm 0.04$ & NS \\
\hline Gizzard \% & $1.26 \pm 0.03$ & $1.27 \pm 0.09$ & $1.10 \pm 0.03$ & $1.05 \pm 0.01$ & $1.04 \pm 0.02$ & NS \\
\hline Heart \% & $0.56 \pm 0.02$ & $0.52 \pm 0.01$ & $0.51 \pm 0.04$ & $0.52 \pm 0.04$ & $0.53 \pm 0.02$ & NS \\
\hline Giblets * \% & $4.50 \pm 0.24$ & $4.26 \pm 0.37$ & $4.45 \pm 0.58$ & $4.53 \pm 0.25$ & $4.09 \pm 0.09$ & NS \\
\hline
\end{tabular}

Sig. $=$ Significance, $N S=$ Non Significant. $*$ Giblets $=$ Liver + Gizzard + Heart

Table (5): Effect of different dietary treatments on some economic traits.

\begin{tabular}{lccccc}
\hline \multirow{2}{*}{ Items } & \multicolumn{5}{c}{ Dietary Treatments } \\
\cline { 2 - 6 } & 1 & 2 & 3 & 4 & 5 \\
\hline Live body weight $(\mathrm{Kg})$ & $1.83 \pm 0.04$ & $2.03 \pm 0.03$ & $2.05 \pm 0.02$ & $2.15 \pm 0.02$ & $2.22 \pm 0.01$ \\
\hline Average feed intake $(\mathrm{Kg})$ & $2.94 \pm 0.06$ & $3.26 \pm 0.08$ & $3.21 \pm 0.05$ & $3.40 \pm 0.03$ & $3.48 \pm 0.04$ \\
\hline Feed Cost (LE) & $18.91 \pm 0.44$ & $20.92 \pm 0.50$ & $20.60 \pm 0.35$ & $21.79 \pm 0.25$ & $22.30 \pm 0.25$ \\
\hline Total Cost $(\mathrm{LE}) \#$ & $31.91 \pm 0.44$ & $33.92 \pm 0.50$ & $33.60 \pm 0.35$ & $34.79 \pm 0.25$ & $35.30 \pm 0.25$ \\
\hline Total Return (LE) * & $45.75 \pm 1.18$ & $50.71 \pm 0.97$ & $51.17 \pm 0.72$ & $53.87 \pm 0.61$ & $55.66 \pm 0.36$ \\
\hline Net Return (LE) & $13.84 \pm 0.77$ & $16.79 \pm 0.48$ & $17.56 \pm 0.37$ & $19.08 \pm 0.36$ & $20.36 \pm 0.11$ \\
\hline Economic Efficiency & $43.33 \pm 1.92$ & $49.47 \pm 0.77$ & $52.24 \pm 0.57$ & $54.83 \pm 0.67$ & $57.67 \pm 0.22$ \\
\hline Relative Economic Efficiency & $100.00 \pm 0.00$ & $114.16 \pm 1.78$ & $120.57 \pm 1.31$ & $126.52 \pm 1.56$ & $133.09 \pm 0.52$ \\
\hline \# Total cost $=$ (feed cost + price of one-day live chicks + incidental costs); & & \\
$*$ According to the local price of Kg sold carcass which was 25.00 L.E. & & &
\end{tabular}

